\title{
Nem daganatos, krónikus progresszív betegségek palliatív ellátása
}

\author{
Radványi Ildikó dr. - Nagy Lajos dr. - Balogh Sándor dr. - Csikós Ágnes dr. \\ Pécsi Tudományegyetem, Általános Orvostudományi Kar, Családorvostani Intézet, Palliatív Tanszék, Pécs
}

\begin{abstract}
Európában évente 2,5 millió ember halálát daganatos és egyéb előrehaladott stádiumú krónikus betegség okozza. Ez a szám várhatóan növekedni fog az európai népesség elöregedése miatt. A krónikus progresszív betegségben szenvedők jelentős hányadának halálát elnyújtott életvégi stádium előzi meg. Ebben a szakaszban a betegeknek súlyos tünetei, fájdalmai vannak, amelyek szükségessé teszik tüneti kezelésüket, palliatív ellátásukat. Sokszor nehézségekbe ütközik a betegek életkilátásainak megítélése, a betegség prognózisának becslése, és emiatt a fokozott palliatív ellátási igényű betegek korai meghatározása, kiválasztása. Az alábbi közlemény a „jó palliatív ellátás” alapelemeinek ismertetése során a leggyakrabban előforduló krónikusbetegség-lefolyási modelleket és azokat a faktorokat is bemutatja, amelyek használata segíti a gyakorló orvosokat abban, hogy könnyebben felismerjék a fokozott palliatív ellátási igényú betegeket és ezáltal már a betegség korábbi szakaszában is a betegek igényeinek megfelelőbb ellátást nyújthassanak. Orv. Hetil., 2015, 156(42), 1703-1709.
\end{abstract}

Kulcsszavak: palliatív ellátás, daganat, krónikus betegség

\section{Palliative care in non-cancer chronic progressive diseases}

\begin{abstract}
Malignant and other chronic diseases cause the death of 2.5 million people in Europe annually. It is anticipated that this number will grow due to the aging of the European population. The death of a significant proportion of patients having progressive chronic disease is preceded by an extended end of life stadium. In this stage the patients have severe symptoms and pain that necessitate their symptomatic treatment and palliative care. The assessment of the life expectancy of patients, estimation of the prognosis of their illness and, therefore, selection of patients with a need of intensified palliative care often pose difficulties. This paper provides a summary on the basic elements of "good palliative care". It introduces the most frequent models for the procession of chronic diseases and those indicators that help practicing doctors to recognise easier patients with a need of intensified palliative care, and as a result provides more adequate medical attendance that is better suited to the specific needs of the patients.
\end{abstract}

Keywords: palliative care, malignant disease, chronic disease

Radványi, I., Nagy, L., Balogh, S., Csikós, Á. [Palliative care in non-cancer chronic progressive diseases]. Orv. Hetil., $2015,156(42), 1703-1709$

(Beérkezett: 2015. július 29.; elfogadva: 2015. augusztus 27.)

\section{Rövidítések}

AIDS = szerzett immunhiány szindróma; ALS = amyotrophiás lateralsclerosis; COPD = krónikus obstruktív tüdőbetegség; NSAID = nem szterod fájdalomcsillapító; $S M=$ sclerosis multiplex; WHO = (World Health Organizaton $)$ Egészségügyi Világszervezet

A WHO definíciója szerint a palliatív ellátás a beteg hatékony, teljes körű ellátása akkor, amikor a betegség nem reagál a gyógyító célú kezelésekre, és amikor a fájdalom és egyéb tünetek enyhítése, megelőzése, valamint a pszichológiai, szociális és spirituális problémák megoldása kiemelkedő jelentőségú feladat. A palliatív ellátás átfogó célja a lehető legmagasabb életminőség biztosítása a beteg és családja számára. A palliatív ellátást nemcsak közvetlenül a halál előtti időszakra kell korlátozni, hanem már a betegség egy korábbi fázisában meg kell kezdeni.

A daganatos és egyéb krónikus betegségekben szenvedők száma világszerte növekszik [1]. A palliatív ellátás koncepciója jórészt a daganatos betegek ellátásából szár- 
mazik, de az Egyesült Államokban és Nyugat-Európa egyes országaiban az előrehaladott stádiumú krónikus betegségekben (krónikus szívelégtelenség, krónikus légzőszervi betegségek, vese- és májelégtelenség, demencia) szenvedő emberek ellátásában is egyre nagyobb teret nyer a palliatív orvoslás. Ideális esetben a palliatív gondozás a kuratív célú terápiás beavatkozásokkal egyidejûleg, már az életet fenyegető betegség diagnózisakor elindul. A betegség progressziója során, a terápiás lehetőségek beszűkülésével párhuzamosan, a komplex ellátást biztosító palliatív ellátás egyre nagyobb teret nyer, majd a betegek életvégi ellátására és halálukat követően a gyászoló családtagok további gondozására is kiterjed. A palliatív gondozás eredményeként a betegek fájdalmának és tüneti terheinek csökkenése miatt a betegek és családjaik életminősége javul, a betegek nagyobb gyakorisággal halnak meg az általuk preferált helyen, a hozzátartozók gyászfeldolgozása sikeresebb, sőt az egészségügyi kiadások is alacsonyabbak $[2,3,4,5]$. Metasztatikus nem kissejtes tüdőrákos betegek körében vizsgálták a korai palliatív gondozás jelentőségét. A „csak” standard kezelést kapó betegcsoport életminőségét és túlélését hasonlították össze a standard kezelés mellé korai palliatív kezelést is kapó betegek életminőség- és túlélésmutatóival. A vizsgálatok igazolták, hogy a korai palliatív ellátásban is részesülő betegeknek nemcsak az életminősége, hanem a túlélése is szignifikánsan javult a „csak” standard kezelésben részesülő betegekéhez képest [6]. A szívelégtelenségben szenvedő betegek csoportjában is történtek hasonló vizsgálatok, amelyek ugyancsak igazolták a korai palliatív gondozás jótékony hatását nemcsak a betegek életminőségére, hanem élettartamára vonatkozólag is [7]. A palliatív ellátás bevezetésével alacsonyabb egészségügyi kiadások, költségek mellett érhető el az előrehaladott daganatos és krónikus betegségekben szenvedő emberek életminőségének javulása [8,9]. Azonban a legtöbb európai országban a palliatív ellátáshoz való hozzáférés az előrehaladott stádiumú nem malignus tüdő- és szívbetegek számára korlátozottabb mértékü, mint a daganatos betegek számára $[10,11,12]$. A hazai rutinszerú betegellátásban pedig a palliatív orvoslást jórészt csak a daganatos betegségekben szenvedők számára tartják fenn, és nem terjed ki más, ugyancsak komplex palliatív gondozást igénylő előrehaladott stádiumú, gyógyíthatatlan krónikus betegség terminális stádiumára. A krónikus betegséggel élő betegek éveken át jó minőségû életet élhetnek a rendszeres szakorvosi gondozás mellett, amely során életmódbeli tanácsadás, a gyógyszeres kezelés rendszeres ellenőrzése, a betegek és hozzátartozóik oktatása is megvalósul. A betegség progressziója során azonban a betegeknek újabb és újabb, egyre súlyosabb tüneteik jelentkezhetnek, amelyek a gyógyszeres kezelés módosítását, speciális eszközös beavatkozásokat, ismételt kórházi ellátásokat tehetnek szükségessé. Ekkorra a betegek ellátásában már több szakorvos is részt vesz, akik általában csak a saját szakterületükön tudnak hatékony segítséget nyújtani a betegeknek, és főként időhiány miatt, csak keveset tudnak törődni a betegek egyre romló egészségi állapotával összefüggő pszichés problémákkal, nehézségekkel. Az életet veszélyeztető krónikus betegségekben szenvedő betegek tünetei (szorongás, depresszió, gyengeség, fulladás, fájdalomszindrómák, székrekedés) nagymértékben hasonlítanak a tumoros betegek panaszaira, tüneteire, amelyek kezelése részben már megoldható a daganatos betegeknél bevezetett komplex terápiákkal $[13,14]$. A daganatos betegek ellátásához hasonlóan, az előrehaladott stádiumú krónikus betegek ellátása során is számos etikai kérdés merülhet fel, mint például az újraélesztés megkísérlésének kérdése, az intenzív osztályos kezelés abbahagyása, a lélegeztetőgépre tétel, a mesterséges táplálás kérdése, vesepótló kezelés alkalmazása, defibrillátor kikapcsolása stb. E kérdések megválaszolására holisztikus szemléletü, palliatív ellátásban is jártas szakemberekből álló interdiszciplináris munkacsoportok kialakítása szükséges, akik nemcsak a beteget, hanem a családot is támogatják a betegágy mellett meghozandó döntésekben.

Összességében elmondható, hogy az életet veszélyeztető krónikus betegségek utolsó stádiumában a betegek, a daganatos betegekhez hasonlóan, egy másfajta, komplex látásmódot igénylő palliatív ellátásra szorulnak. Mivel Magyarországon a palliatív ellátási forma a hospice-tevékenységgel kapcsolódik össze és egyelőre strukturált korai palliatív gondozás nem múködik, minden gyakorló orvosnak törekednie kell arra, hogy a lehető legjobb életminőséget biztosító ellátást nyújtsa a gyógyíthatatlan betegek és családjaik számára. Ehhez azonban fel kell ismernie a fokozott palliatív ellátási igénnyel bíró betegeket, valamint ismernie és alkalmaznia kell a „jó palliatív ellátás" alapelemeit.

\section{A ,jó palliatív ellátás" alapelemei}

A palliatív gondozás lényeges elemei közé tartozik az adekvát tüneti kezelés, a gondos ápolás és az őszinte, nyílt kommunikáció.

\section{Tüneti kezelés}

A palliatív ellátás egyik legfontosabb alapeleme a magas szakmai tudást igénylő, adekvát tüneti kezelés. Számos vizsgálatot terveztek az előrehaladott stádiumú krónikus betegek tüneti terheinek felmérésére. A vizsgálatok adatai alapján számos tünet - köztük a fájdalom, nehézlégzés, gyengeség, alvászavar - a szívelégtelenségben szenvedő és a krónikus obstruktív tüdőbetegségben (COPD) szenvedő betegeknél ugyanúgy nagy gyakorissággal fordul elö, mint daganatos betegségek esetén [13]. Mindezek ellenére a krónikus betegségekben szenvedők tüneteik enyhítésére, palliatív célból kevesebb gyógyszert kapnak, mint a daganatos betegek [15]. Az 1. táblázat összefoglalja a daganatos, COPD-s és szívelégtelen betegek tüneti terheit. 
1. táblázat $\mid$ Tünetek gyakorisága (\%) előrehaladott stádiumú krónikus betegségekben

\begin{tabular}{llll}
\hline Tünetek & $\begin{array}{l}\text { Daganat } \\
(\%)\end{array}$ & $\begin{array}{l}\text { COPD } \\
(\%)\end{array}$ & $\begin{array}{l}\text { Szívelégtelenség } \\
(\%)\end{array}$ \\
\hline Fájdalom & $35-96$ & $34-77$ & $41-78$ \\
Fáradékonyság & $32-90$ & $68-80$ & $69-82$ \\
Fulladás & $10-70$ & $90-95$ & $60-88$ \\
Depresszió & $3-77$ & $37-71$ & $9-56$ \\
Alvászavar & $9-69$ & $55-65$ & $36-48$ \\
\hline
\end{tabular}

Krónikus progresszív betegségek esetén alapvető fontosságú, hogy a betegek, a betegségük stádiumának megfelelően, az irányelvekben szereplő gyógyszeres kezelést megkapják, mert ezek a gyógyszerek megfeleló dózisban és kombinációban alkalmazva alapvető szerepet játszanak az adott alapbetegségre jellemző tünetek kontrollálásában. Azonban a betegség progressziójával párhuzamosan ezek a betegségmódosító vagy gyógyító célú terápiás lehetôségek kimerülnek, és egyre nagyobb szerepet kap a betegek komplex palliatív gondozása.

\section{Szorongás, depresszió}

Krónikus, progresszív betegségek nagyon gyakran járnak együtt depresszióval, szorongással. Az előrehaladott COPD-s betegek körülbelül 40\%-a szenved súlyos depressziós tünetektől. A depresszió és COPD tüneteinek átfedése miatt a depresszió sokszor nehezen diagnosztizálható. A betegek életminőségének romlása szorosabb korrelációt mutat a depresszió tüneteinek jelenlétével, mint a COPD súlyosságával [16]. Szívelégtelenségben szenvedő betegek között a klinikailag szignifikáns depresszió prevalenciája több mint $20 \%$ [17]. A depresszió megjelenésével párhuzamosan szívelégtelenségben növekszik a mortalitás [18]. A depresszió és szorongás nagymértékben rontja a betegek életminőségét, felerősíti a testi tüneteket, növeli a hospitalizáció esélyét [17, 19]. A palliatív orvoslás során fontos a betegek pszichés tüneteinek felismerése, mentálhigiénés szakemberek bevonásával az antidepresszív és anxiolitikus gyógyszeres kezelési lehetőségek kiválasztása, illetve pszichoterápia alkalmazásával a betegek életminőségének javítása.

\section{Légszomj}

Krónikus progresszív cardiopulmonalis betegségekben az életminőséget jelentősen rontó, gyakori tünet a fulladás. Fontos a fulladás hátterében álló okok felderítése, és lehetőség szerint oki kezelés alkalmazása. Általában a nehézlégzés az alapbetegségre adott, evidenciákon alapuló kezelési lehetôségekkel, gyógyszeres kombinációkkal csökkenthető. Azonban a gyógyíthatatlan krónikus betegségek terminális stádiumában elóállhat az az állapot, amikor minden lehetséges oki kezelés ellenére a fulladás továbbra is fennáll, a fulladás oka irreverzibilis, vagy spe- cifikus oki kezelésre nincs mód. Ilyenkor a beteg légszomjérzését opiátok adásával csökkenthetjük, illetve a fulladáshoz társult nagyfokú szorongást benzodiazepinekkel mérsékelhetjük [20].

Az opioidok a légszomj megélését csökkentik szedatoanxiolitikus és fájdalomcsillapító hatásuk következményeként [21]. Perifériás vasodilatator hatásuk folytán a szív előterhelését csökkentik, direkt légúti hatásaik révén pedig mérsékelik a nyákszekréciót és csillapítják a köhögést. Napjainkban is megtapasztalható a súlyos dyspnoéban szenvedő betegek kezelését végző orvosok opioidok használatával szembeni aggodalma, azok légzésdepreszsziót okozó hatása miatt. Azonban számos vizsgálat igazolta, hogy a nehézlégzés enyhítésére használt opioidok nem csökkentik a betegek élettartamát, nem ronják életkilátásaikat [22, 23, 24, 25]. A 2. táblázat összefoglalja a fulladás tüneti kezelésére használható opioidok adagolását és dózisát különböző súlyosságú és jellegû́ fulladás esetén opiátkezelésben még nem részesült és opiátot már használó betegek esetén.

2. táblázat | Opiátok adagolása különböző súlyosságú és jellegű fulladás esetén

\begin{tabular}{lll}
\hline $\begin{array}{l}\text { Fulladás } \\
\text { súlyossága }\end{array}$ & $\begin{array}{l}\text { Opiátkezelésben még nem } \\
\text { részesült }\end{array}$ & $\begin{array}{l}\text { Opiátkezelésben } \\
\text { részesül }\end{array}$ \\
\hline Enyhe & $\begin{array}{l}\text { Állandó fulladás esetén: } \\
\text { dihidrokodein } 2 \times 60 \mathrm{mg} \\
\text { (maximum } 240 \mathrm{mg})\end{array}$ & $\begin{array}{l}\text { Opiátdózis emelése } \\
25-50 \%-k a l\end{array}$ \\
& $\begin{array}{l}\text { Periodikus fulladás esetén: } \\
2 \% \text {-os etil-morfin } 25-50 \text { csepp } \\
\text { (maximum } 180 \text { csepp } / \text { nap) }\end{array}$ \\
& $\begin{array}{l}\text { Morfin-szulfát-cseppek: } \\
\text { Súlyos }\end{array}$ & $\begin{array}{l}\text { Opiátdózis emelése } \\
\text { Parenteralis morfin: }\end{array}$ \\
& $\begin{array}{l}25-50 \%-5 \text { mal } \\
\text { Óránként }\end{array}$ \\
\hline
\end{tabular}

Daganatos és COPD-s betegeket vizsgáló tanulmányok nem támasztották alá a benzodiazepinek közvetlen fulladáscsökkentő hatását. Azonban a fulladáshoz társuló szorongás csökkentésére adhatunk kiegészítésként benzodiazepineket, ha opiátokkal vagy egyéb nem gyógyszeres beavatkozásokkal nem sikerült mérsékelni a fulladást [26]. A benzodiazepinek és opioidok kis dózisban történő együttes adagolása nem befolyásolja a mortalitást [27]. A 3. táblázat összefoglalja a fulladás tüneti kezelésére használható benzodiazepinek adagolását, dózisát.

Fulladás kezelésére oxigénkezelést akkor indikálunk, ha a fulladó beteg szobalevegő́n hypoxiás [28, 29]. Az oxigén kezdő dózisa nazális katéteren keresztül alkalmazva 1-31/perc, amely szükség esetén 61 /perc dózisig emelhető. Célunk, hogy az oxigén parciális nyomása 55-60 Hgmm, a szaturáció pedig 88-90\% közötti legyen. Nyugalmi dyspnoe esetén lehetőleg ne folyamatosan, hanem a gyógyszeres kezelés kiegészítéseként csak 
3. táblázat | Benzodiazepinek adagolása fulladás esetén

\begin{tabular}{ll}
\hline Gyógyszer & Adagolás \\
\hline Lorazepam & $\begin{array}{l}0,5-1 \mathrm{mg} / \mathrm{h} \text { a fulladás megszúnéséig, majd } \\
4-6 \text { óránként }\end{array}$ \\
Midazolam & $\begin{array}{l}0,5 \mathrm{mg} \text { iv. } 15 \text { percenként, majd folyamatos sc. } \\
\text { infúzió }\end{array}$ \\
Diazepam & $\begin{array}{l}\text { 2-10 mg per os óránként a fulladás } \\
\text { megszúnéséig, majd 6-8 óránként }\end{array}$ \\
Clonazepam & $0,25-2$ mg per os 12 óránként \\
\hline
\end{tabular}

meghatározott időtartamban adjuk. Terhelési dyspnoe esetén a fizikai aktivitás előtt és után, esetleg hordozható oxigénpalack használata esetén terhelés alatt kaphatja a beteg.

\section{Fájdalom}

A krónikus, progresszív betegségekben szenvedő embereknek gyakori, életminőséget rontó tünete a fájdalom. A fájdalomnak számos oka lehet, amelyet a fájdalomra vonatkozó anamnézis, az alapos fizikális vizsgálat és szükség esetén eszközös vizsgálatok tisztázhatnak. Ha a fájdalom csillapítására specifikus oki kezelési lehetőség nem áll rendelkezésre, akkor a WHO ajánlásában szereplő analgetikus lépcső szerint járhatunk el, a fájdalom típusának és erősségének megfelelően. Különös figyelmet kell szentelnünk azonban annak, hogy bizonyos fájdalomcsillapító gyógyszerek egyes alapbetegségek esetén kontraindikáltak. Például a nem szteroid fájdalomcsillapítók (NSAID) vízretenciót okozó hatásaik miatt nem javasoltak szívelégtelenségben szenvedő betegek fájdalomcsillapítására.

\section{Ápolás}

A palliatív ellátás alapvető elemei közé tartozik a lelkiismeretes, gondos, szeretetteljes ápolás, valamint a beteg és családjának együttes támogatása. Mindezeken kívül fontos a betegek számára az egyenlő ellátási esélyek biztosítása. Magyarországon az egyenlő ellátási esélyek, sajnos, nem valósulhatnak meg. Ennek az oka részben az, hogy a hospice-palliatív otthoni ellátás jelenleg csak néhány betegcsoportban - mint a daganatos betegségek, amyotrophiás lateralsclerosis (ALS), sclerosis multiplex $(\mathrm{SM})$, szerzett immunhiány szindróma (AIDS) - finanszírozott, az előrehaladott stádiumú, krónikus betegségekben szenvedők - szervi elégtelenség, COPD, demencia, stroke, idős, többszörös krónikus betegségben szenvedők - nem juthatnak hozzá ehhez az ellátási formához. A finanszírozott betegcsoportokon belül is korlátozott az ellátásba vonható betegek száma, mivel a finanszírozás mértéke nem igazodik a hospice-palliatív ellátás ismertségével és fejlődésével párhuzamosan egyre növekvő ellátási igényekhez.

\section{Kommunikáció}

A palliatív ellátás egyik legfontosabb alapeleme a betegekkel és családjukkal való adekvát kommunikáció. A kommunikáció során fel kell mérnünk a beteg és családja ismeretét a betegség természetéről, prognózisáról, majd ezt követően a beteg nyitottságának megfelelően őszintén, nyíltan beszélnünk kell a betegség várható kimeneteléről. A továbbiakban szükséges a betegeket tájékoztatni az ellátás, kezelés lehetőségeiről és felmérni a betegek életvégi ellátásokra, beavatkozásokra, valamint az ellátás és esetleges halál bekövetkeztének helyére vonatkozó kívánságait. Az ellátásra vonatkozó tervet a betegek és családjuk bevonásával közösen kell elkészíteni, a beteg kívánságainak szem előtt tartásával. Ezt a folyamatot nevezzük az ellátás jövőbeni tervezésének [30]. Az ellátás előre tervezése által hatékonyabbá válik az életvégi ellátás is, mivel csökken a beteg és hozzátartozók szorongása, a depresszió előfordulásának gyakorisága és növekszik a betegek és családjuk ellátással kapcsolatos elégedettsége [31].

A betegekkel és családjukkal való kommunikáció során elóállhat az a helyzet, amikor páciensünk felteszi nekünk a rettegett kérdést, hogy mennyi ideje van még hátra. Ilyenkor általában arra is kíváncsi - ha nem is meri megkérdezni -, hogy mi fog történni vele, hogyan fog alakulni a betegsége, hogyan fog meghalni. Mindezek megválaszolásához segítséget nyújthat számunkra a típusos betegséglefolyási modellek ismerete. Betegséglefolyási modellekben gondolkozva feltérképezzük a diagnózistól az elmúlásig vezető utat, szélesebb időkeretet nyerhetünk arra, hogy a betegek várható szükségleteit felmérjük és a rendelkezésre álló egészségügyi és szociális ellátásokhoz való hozzáférést megszervezzük. Ezen modellek segítenek nekünk a tervezésben és az ellátás megfelelő kivitelezésében. Ha a betegek és hozzátartozóik megértik a betegség lefolyását, ez segítséget jelenthet számukra is az adott szituáció kontrollálásában és felkészíti őket arra, hogy könnyebben megbirkózzanak a várható kihívásokkal.

\section{Betegséglefolyási modellek}

A három uralkodó, halálhoz vezető betegségcsoportra - daganat, szervi elégtelenség és időskori végelgyengülés - különböző betegséglefolyás jellemző [32].

Rákra jellemző egy viszonylag hosszú, hetekben, hónapokban, esetleg években mérhető jó funkcionális állapot, amelyet a funkcionális és fizikális állapotban bekövetkező hirtelen, gyors hanyatlás követ, amely halálhoz vezet (1. ábra).

A szervi elégtelenségre - mint a szív- és légzőszervi elégtelenség, máj- és veseelégtelenség - egy, az előzőtől eltérő betegséglefolyás jellemző. A szervi elégtelenségek esetében a funkcionális és fizikális állapot lassú hanyatlása figyelhető meg. A betegség progressziója során hirtelen, sokszor kiszámíthatatlan állapotrosszabbodások léphet- 


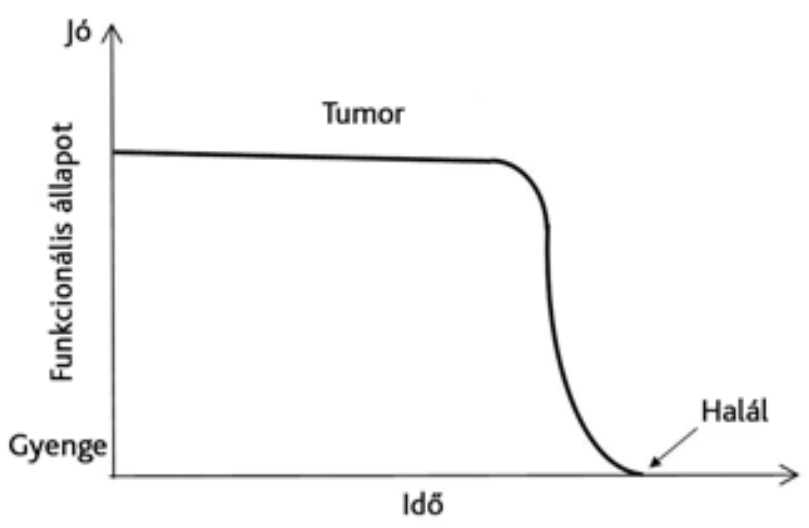

1. ábra | Betegséglefolyási görbe daganatos megbetegedésekben

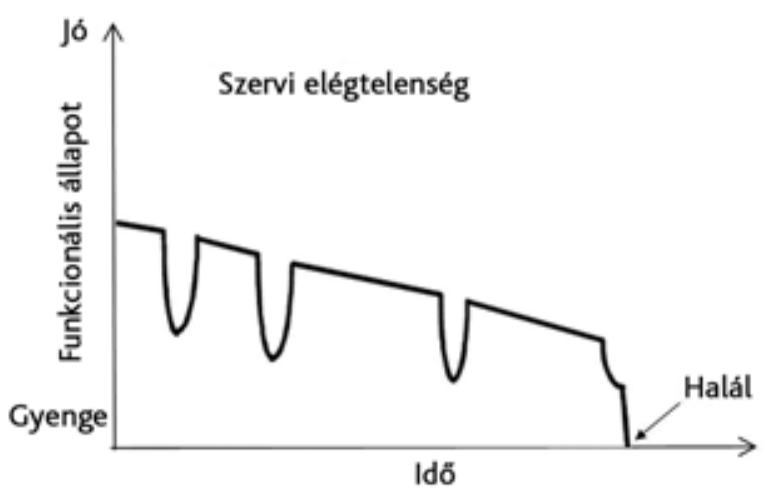

2. ábra | Betegséglefolyási görbe szervi elégtelenségben

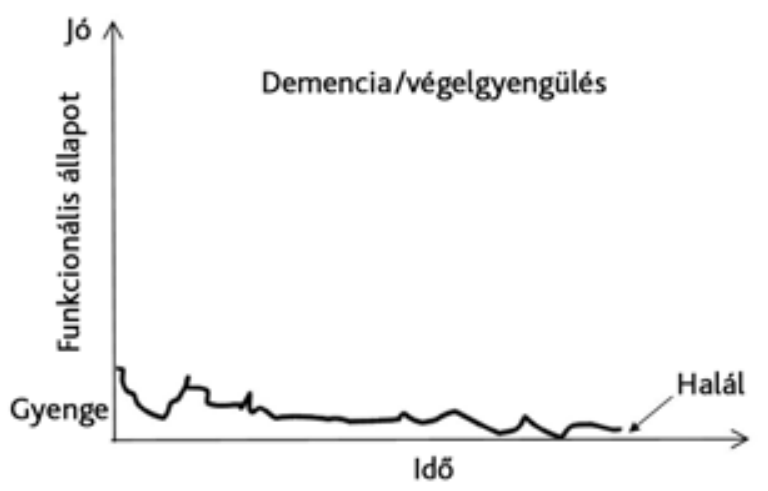

3. ábra | Betegséglefolyási görbe demencia és végelgyengülés esetén

nek fel, amelyek gyakori sürgősségi ellátáshoz, kórházi felvételekhez vezethetnek. Ezen időszakok bármelyikében a halál hirtelen, váratlanul bekövetkezhet. Ha a kezeléseknek köszönhetően a beteg túlél egy epizódot, akkor szinte olyan állapotba kerülhet, mint az epizód előtt volt. De egy bizonyos ponton, a betegség elörehaladásával párhuzamosan, a terápiás lehetőségek kimerülnek és a bekövetkező halál hirtelennek, váratlannak tünhet (2. ábra).

A végelgyengülésre és demenciára a hosszan tartó hanyatlás jellemző (3. ábra). A halál gyakran egy korábbi életszakaszban jól kezelhető fertőzés, influenza, tüdőgyulladás, combnyaktörés, cachexia vagy dehidráció miatt következik be. Társadalmunk elöregedése miatt, becslések szerint 2050-re, világszerte megháromszorozódik a 65 év felettiek aránya [33]. Ezen 65 év felettiek kétharmada két vagy több krónikus betegség okozta, több hónapig, esetleg évig tartó „sérülékeny öregségi fázis" után fog meghalni, és körülbelül csak egyötödük egy felismerhető végső fázist követően [34].

A különböző betegséglefolyási modelleket és ennek megfelelően különböző palliatív ellátási igényeket tekintetbe véve, más-más palliatív ellátási stratégia szükséges az egyes betegségcsoportokban. Az elmúlt 40 évben a palliatív ellátási stratégiák kifejlesztésére elsősorban a daganatos betegek csoportjában került sor, náluk került meghatározásra a betegség azon stádiuma, ahol a palliatív ellátásra feltétlenül szükség van. Az előrehaladott krónikus betegségekben szenvedők gyakran nem kapnak palliatív ellátást és megfelelő életvégi támogatást, pedig Európában 3 halálesetből 2 nem daganatos, hanem előrehaladott krónikus szív-ér rendszeri és légzőszervi betegség miatt következik be [35].

Tehát, ha a daganatos betegségek lefolyási modellje alapján próbáljuk azonosítani az előrehaladott stádiumú krónikus szervi elégtelenségben szenvedő azon betegeket, akik életük utolsó szakaszába léptek, akkor a betegeink jelentős hányadát elveszíthetjük, mielőtt még megfelelő ellátást kaphattak volna.

\section{Palliatív ellátási igényt jelző faktorok}

Léteznek olyan általános és az adott alapbetegségre jellemző betegségspecifikus indikátorok, amelyek a fokozott palliatív ellátási igényt jelzik és segítenek nekünk, gyakorló orvosoknak abban, hogy már a betegség egy korábbi szakaszában is felismerjük azon betegeinket és családjaikat, akik szerteágazó problémáik miatt egy komplexebb, holisztikus szemléletű ellátást igényelnek $[36,37]$.

Az egyik általános faktor az úgynevezett „meglepődéskérdés". A kezelőorvos megkérdezi saját magától, hogy meg lenne-e lepődve azon, hogyha az adott betege egy éven belül meghalna. Ha erre a kérdésre a válasza, hogy nem lenne meglepődve, akkor erről a betegéről el kell kezdenie másképp gondolkodni. Ebben a szakaszban már nagyon fontos beszélgetni a beteggel és családjával a betegség várható lefolyásáról, a lehetséges komplikáló tényezőkről, felmérni a beteg igényeit, az életvégi ellátásra vonatkozó tervet elkészíteni, hogy képesek legyünk a beteg igényeinek legmegfelelőbb ellátást biztosítani.

A betegség rosszabbodását előre jelzô általános prognosztikus indikátornak tekinthetjük a beteg romló performance státusát, mint például a Karnofsky-index 50\% alá csökkenését, ami azt mutatja, hogy a beteg a napközbeni időszak több mint felét ágyban tölti. Az önellátó képesség csökkenése, a másoktól való függőség fokozó- 
dása, az egyre gyakrabban ismétlődő sürgősségi ellátások és hospitalizációk, a tápláltsági állapot romlását jelző, fél év alatt a testsúly 10\%-át meghaladó súlycsökkenés és szérumalbumin $25 \mathrm{~g} / 1$ alá csökkenése ugyancsak a betegség előrehaladását jelző általános prognosztikai faktoroknak tekinthetők [36].

A betegségspecifikus palliatív ellátási igényt jelző faktorok az adott alapbetegség progresszióját, a beteg állapotának jelentős rosszabbodását és ezzel párhuzamosan a palliatív ellátási igény növekedését jelzik számunkra.

A daganatok esetében egy rossz prognózisú, metasztatikus daganat jelenléte önmagában is fokozott palliatív ellátási igényt jelző betegségspecifikus indikátornak tekinthető.

COPD-s betegeknél a súlyos légúti obstrukció $\left(\mathrm{FEV}_{1}\right.$ $<30 \%$ ) vagy restriktív deficit (vitálkapacitás<60\%), tartós oxigénkezelés kritériumainak fennállása $\left(\mathrm{PaO}_{2}<55\right.$ $\mathrm{Hgmm}$ ), ortopnoe, visszatérő légúti infekciók miatti gyakoribb hospitalizáció, jobbszívfél-elégtelenség, nyugalmi tachycardia jelzik a betegség elörehaladottabb stádiumát és a fokozottabb palliatív ellátási igényt [38, 39].

Szívelégtelenség esetén az optimálisan tolerálható, evidence-based medicine alapján alkalmazott terápia mellett nyugalomban vagy minimális terhelésre fellépó nehézlégzés, vagy mellkasi fájdalom (NYHA IV. stádium), a szívelégtelenség exacerbatiói miatti gyakoribbá váló hospitalizáció és sürgősségi ellátás, diuretikumkezelés melleti testsúlynövekedés és a kórelőzményben szereplő szívmegállás mind a betegség egy igen előrehaladott stádiumát jelzik, amely stádiumban a betegek és családjaik már egy komplex, holisztikus látásmódot igénylő ellátásra szorulnak [36, 39].

\section{Következtetések}

Az élet vége felé közeledve, alapbetegségtől függetlenül, minden embernek alapvető joga, hogy a lehető legjobb életminőség biztosítását megcélzó palliatív ellátáshoz hozzájusson. Magyarországon nem daganatos, krónikus progresszív betegségekben szenvedő betegek számára strukturált palliatív gondozás nem múködik, az otthoni palliatív ellátáshoz jórészt csak daganatos betegek juthatnak hozzá. Azonban az életet veszélyeztető krónikus betegségek végső stádiumába jutó betegek - a daganatos betegekhez hasonlóan - sokféle, életminőségüket jelentősen rontó testi és pszichés tünettől szenvednek, amelyek miatt komplex látásmódot igénylő palliatív ellátásra szorulnak. Számos vizsgálat felhívta a figyelmet a korai palliatív gondozás életminőségre és túlélésre gyakorolt kedvező hatásaira. A palliatív ellátási igényt jelző általános és betegségspecifikus faktorok ismerete segíti a gyakorló orvosakat abban, hogy megfelelő időben megkezdjék betegeik palliatív ellátását. Az ellátás alapvető eleme a testi tünetek enyhítésén kívül a pszichoszociális és spirituális problémák megoldása, a betegek gondos, szeretetteljes ápolása és a családtagok támogatása a betegség és gyász idején. Mindehhez nélkülözhetetlen a beteggel és családjával való őszinte bánásmód és a beteg igényeinek megfelelő nyílt kommunikáció. A prognózisról való kommunikációt és az ellátás további tervezését segíti a különböző krónikus betegséglefolyási modellek ismerete.

Anyagi támogatás: A közlemény megírása, illetve a kapcsolódó kutatómunka anyagi támogatásban nem részesült.

Szerzôi munkamegosztás: R. I.: Szakirodalom gyújtése, kézirat megszövegezése, ábrák, táblázatok elkészítése. N. L.: Szakmai vélemény. B. S.: Szakmai vélemény hozzáadása. Cs. Á.: Szakirodalom gyüjtése, szakmai vélemény hozzáadása. A cikk végleges változatát mindegyik szerző elolvasta és jóváhagyta.

Érdekeltségek: A szerzőknek nincsenek érdekeltségeik.

\section{Irodalom}

[1] Vos, T., Flaxman, D. A., Naghavi, M., et al.: Years lived with disability (YLDs) for 1160 sequelae of 289 diseases and injuries 1990-2010: a systematic analysis for the Global Burden of Disease Study 2010. Lancet, 2012, 380(9859), 2163-2196.

[2] Obermeyer, Z., Makar, M., Abujaber, S., et al.: Association between the Medicare hospice benefit and health care utilization and costs for patients with poor-prognosis cancer. JAMA, 2014, 312(18), 1888-1896.

[3] Zhang, B., Wright, A. A., Huskamp, H. A., et al.: Health care costs in the last week of life: associations with end of life conversations. Arch. Intern. Med., 2009, 169(5), 480-488.

[4] Casarett, D., Pickard, A., Bailey, F. A., et al.: Do palliative care consultations improve patient outcomes? J. Am. Geriatr. Soc., $2008,56(4), 593-599$.

[5] Morrison, R. S., Penrod, J. D., Cassel, J. B., et al.: Cost savings associated with US hospital palliative care consulation programs. Arch. Intern. Med., 2008, 168(16), 1783-1790.

[6] Temel, J. S., Greer, J. A., Muzikansky, A., et al.: Early palliative care for patients with metastatic non-small-cell lung cancer. N. Engl. J. Med., 2010, 363(8), 733-742.

[7] Connor, S. R., Pyenson, B., Fitch, K., et al.: Comparing hospice and nonhospice patient survival among patients who die within a three-year window. J. Pain Symptom Manage., 2007, 33(3), 238-246

[8] Greer, J. A., Jackson, V. A., Meier, D. E., et al.: Early integration of palliative care services with standard oncology care for patients with advanced cancer. CA Cancer J. Clin., 2013, 63(5), 349363.

[9] Taylor, D. H. Jr., Bull, J., Zhong, X., et al.: The effect of palliative care on patient functioning. J. Palliat. Med., 2013, 16(10), 1227-1231.

[10] Gadoud, A., Jenkins, S. M., Hogg, K. J.: Palliative care for people with heart failure: Summary of current evidence and future direction. Palliat. Med., 2013, 27(9), 822-828.

[11] Boland, J., Martin, J., Wells, A. U., et al.: Palliative care for people with non-malignant lung disease: Summary of current evidence and future direction. Palliat. Med., 2013, 27(9), 811-816.

[12] Beernaert, K., Cohen, J., Deliens, L., et al.: Referral to palliative care in COPD and other chronic diseases: a population-based study. Respir. Med., 2013, 107(11), 1731-1739.

[13] Solano, J. P., Gomes, B., Higginson, I. J.: A comparison of symptom prevalence in far advanced cancer, AIDS, heart disease, 
chronic obstructive pulmonary disease and renal disease. J. Pain Symptom Manage., 2006, 31(1), 58-68.

[14] Edmonds, P., Karlsen, S., Khan, S., et al.: A comparison of the palliative care needs of patients dying from chronic respiratory diseases and lung cancer. Palliat. Med., 2001, 15(4), 287-295.

[15] McKinley, R. K., Stokes, T., Exley, C., et al.: Care of people dying with malignant and cardiorespiratory disease in general practice. Br. J. Gen. Pract., 2004, 54(509), 909-913.

[16] Stage, K. B., Middelboe, T., Stage, T. B., et al.: Depression in COPD - management and quality of life considerations. Int. J. Chron. Obstruct. Pulmon. Dis., 2006, 1(3), 315-320.

[17] Rutledge, T., Reis, V. A., Linke, S. E., et al.: Depression in heart failure: a meta-analytic review of prevalence, intervention effects, and associations with clinical outcomes. J. Am. Coll. Cardiol., 2006, 48(8), 1527-1537.

[18] Jiang, W., Kuchibhatla, M., Clary, G. L., et al.: Relationship between depressive symptoms and long-term mortality in patients with heart failure. Am. Heart J., 2007, 154(1), 102-108.

[19] Salerno, F. G., Carone, M.: Anxiety and depression in COPD. Multidiscip. Respir. Med., 2011, 6(4), 212-213.

[20] LeGrand, S. B., Khawam, E. A., Walsh, D., et al.: Opioids, respiratory function, and dyspnea. Am. J. Hosp. Palliat. Care, 2003, 20(1), 57-61.

[21] Jennings, A. L., Davies, A. N., Higgins, J. P., et al.: A systematic review of the use of opioids in the management of dyspnoea. Thorax, 2002, 57(11), 939-944.

[22] Chan, J. D., Treece, P. D., Engelberg, R. A., et al.: Narcotic and benzodiazepine use after withdrawal of life support: association with time to death? Chest, 2004, 126(1), 286-293.

[23] Daly, B. J., Thomas, D., Dyer, M. A.: Procedures used in withdrawal of mechanical ventilation. Am. J. Crit. Care, 1996, 5(5), 331-338.

[24] Stone, P., Phillips, C., Spruyt, O., et al.: A comparison of the use of sedatives in a hospital support team and in a hospice. Palliat. Med., 1997, 11(2), 140-144.

[25] Thorns, A., Sykes, N.: Opioid use in last week of life and implications for end-of-life decision-making. Lancet, 2000, 356(9227), 398-399.

[26] Simon, S. T., Higginson, I. J., Booth, S., et al.: Benzodiazepines for the relief of breathlessness in advanced malignant and non-malignant diseases in adults. Cochrane Database Syst. Rev., 2010, 20(1), CD007354.
[27] Ekström, M. P., Bornefalk-Hermansson, A., Abernethy, A. P., et al.: Safety of benzodiazepines and opioids in very severe respiratory disease: national prospective study. Br. Med. J., 2014, 348, g445.

[28] Abernethy, A. P., McDonald, C. F., Frith, P. A., et al.: Effect of palliative oxygen versus room air in relief of breathlessness in patients with refractory dyspnoea: a double-blind, randomised controlled trial. Lancet, 2010, 376(9743), 784-793.

[29] Uronis, H. E., Abernethy, A. P.: Oxygen for relief of dyspnea: what is the evidence? Curr. Opin. Support Palliat. Care, 2008, $2(2), 89-94$.

[30] Emanuel, L. L., von Gunten, C. F., Ferris, F. D.: Advance care planning. Arch. Fam. Med., 2000, 9(10), 1181-1187.

[31] Detering, K. M., Hancock, A. D., Reade, M. C., et al.: The impact of advance care planning on end of life care in elderly patients: randomised controlled trial. Br. Med. J., 2010, 340, cl345.

[32] Murray, S. A., Kendall, M., Boyd, K., et al.: Illness trajectories and palliative care. Br. Med. J., 2005, 330(7498), 1007-1011.

[33] United Nations: World Population Prospects: The 2012 Revision. http://esa.un.org/wpp.

[34] Lynn, J., Forlini, J. H.: "Serious and complex illness" in quality improvement and policy reform for end-of-life care. J. Gen. Intern. Med., 2001, 16(5), 315-319.

[35] Causes of death statistics, 2014. http://epp.eurostat.ec.europa. eu/statistics_explained/index.php/Causes_of_death_statistics

[36] The GSF Prognostic Indicator Guidance, 4th edition, 2011. http://www.goldstandardsframework.org.uk

[37] MCCN Guidelines for the identifications of patients in the last 12 months of life, 2012. http://www.mccn.nhs.uk/fileuploads/ File/Guidelines

[38] Weiss, B. D., Lee, E.: Hospice eligibility for patients with COPD. 2010. http://202.154.59.182/ejournal/files/A\%20Resource\% 20for\%20Providers.pdf

[39] Thoonsen, B., Engels, Y., van Rijswijk, E..: Early identification of palliative care patients in general practice: development of RADbound indicators for Palliative Care Needs (RADPAC). Br. J. Gen. Pract., 2012, 62(602), e625-e631.

(Radványi Ildikó dr., Pécs, Rákóczi u. 2., 7623 e-mail: radvanyiildi@gmail.com)

\section{Eladó praxis}

Veszprém belvárosi, új épitésủ rendelőben müködő, felnőtt háziorvosi körzet praxisjoga eladó.

Kártyaszám: 1370, alkalmazott egy fö, havi finanszírozás 1 M Ft.

Érdeklődni: +36-30-526-1990. 